\title{
GlencoreXstrata... The Profitable and Untethered March to Global Resource Dominance!
}

\author{
By Nina Aversano* \\ Titos Ritsatos ${ }^{\dagger}$
}

\begin{abstract}
Motivated by the economic causes and effects of their merger in 2013, we study the expansion strategy deployment of Glencore International plc. and Xstrata plc., before and after their merger. While both companies went through a series of international acquisitions during the last decade, their merger is strengthening effective vertical integration in critical resource and commodity markets, following Hymer's theory of internationalization and Dunning's theory of Eclectic Paradigm. Private existence of global dominant positioning in vital resource markets, posits economic sustainability and social fairness questions on an international scale. Glencore is alleged to have used unethical business tactics, increasing corruption, tax evasion and money laundering, while attracting the attention of human rights organizations. Since the announcement of their intended merger, the company's market performance has been lower than its benchmark index. Glencore's and Xstrata's economic success came from operating effectively and efficiently in markets that scare off risk-averse companies. The new GlencoreXstrata is not the same company anymore. The Company's new capital structure is characterized by controlling presence of institutional investors, creating adherence to corporate governance and increased monitoring and transparency. Furthermore, when multinational corporations like GlencoreXstrata increase in size attracting the attention of global regulation, they are forced by institutional monitoring to increase social consciousness. When ensuring full commitment to social consciousness acting with utmost concern with regard to their commitment by upholding rules and regulations of their home or host country, they have but to become "quasi-utilities" for the global industry.
\end{abstract}

\section{Introduction and Company Overview}

GlencoreXstrata is an Anglo-Swiss multinational commodity trading and mining company headquartered in Baar, Switzerland and registered in Saint

*Assistant Professor, College of Mount Saint Vincent, USA.

${ }^{\dagger}$ Assistant Professor, College of Mount Saint Vincent, USA.

https://doi.org/10.30958/ajbe.1-2-1

doi=10.30958/ajbe.1-2-1 
Helier, Jersey. The company was created through a merger of Glencore with Xstrata on May 2, 2014. It is ranked twelfth in the Fortune Global 500 list of the world's largest companies with combined revenues of over $\$ 68$ billion dollars. The merger brought together two large and powerful businesses that have had a long standing and intertwined history. The merged entity employs 200,000 people globally, and operates in over 90 locations and 50 countries. The histories of Glencore and Xstrata have been inextricably connected since at least 2002 when Xstrata acquired Australian and South African coal assets of Glencore, the largest shareholder in Xstrata at the time. At the same time Xstrata listed on the London Exchange. The two companies have been working together for the past ten (10) years under a series of marketing agreements.

Glencore's business began in 1974 as Marc Rich, + Co AG, initially focused on the physical marketing of ferrous and non-ferrous metals, minerals and crude oil. He soon expanded his product offering to include oil products as well. Glencore acquired an established Dutch grain trading company which became the basis for its agricultural products business and later added coal to its energy products business segment. Beginning in 1987, they moved from a purely commodity marketing company into a diversified natural resources group through key acquisitions in mining, smelting, refining and processing in the three (3) principal business segments. In 1994, the founder of the Company sold his stake by way of a management buyout. In March, 2002, Xstrata plc was created through an initial public offering on the London and Swiss stock exchanges and at the same time acquired Glencore's coal assets. The successful acquisition and integration of M/M in 2003 and Falconbridge in 2006 were key elements in the transformation of Xstrata. The shares of Glencore International plc listed on the London and Hong Kong Exchanges since May 2011.

Currently, the new entity GlencoreXstrata holds $60 \%$ of the zinc market, $50 \%$ of the copper market, $45 \%$ of the lead market, $38 \%$ of the alumina market, and $28 \%$ of the thermal coal market. The Company is one of the world's largest global diversified natural resource companies and is one of the ten biggest companies within the FTSE 100 Index. The Group's industrial and marketing activities are supported by a global network. Their diversified operations comprise of over 150 mining and metallurgical sites, offshore oil production assets, farms and agricultural facilities. GlencoreXstrata produces products that impact the day to day life of the industrialized world. They mine and produce those commodities needed for technology, food and energy that are consumed each day by a large portion of society.

The following figure demonstrates where Glencore stood before and after the merger with Xstrata. Using Copper and Zinc as examples, prior to the merger, Glencore was the \#4 producer of Copper and \#1 producer of Zinc worldwide. After the merger, GlencoreXstrata is now \#1 in Zinc, and \#3 in Copper. As a consequence of the merger, Glencore saw a shift from its prior market position to that of \#1 after the union with Xstrata. 
Figure 1. Market Positioning before and after the Merger
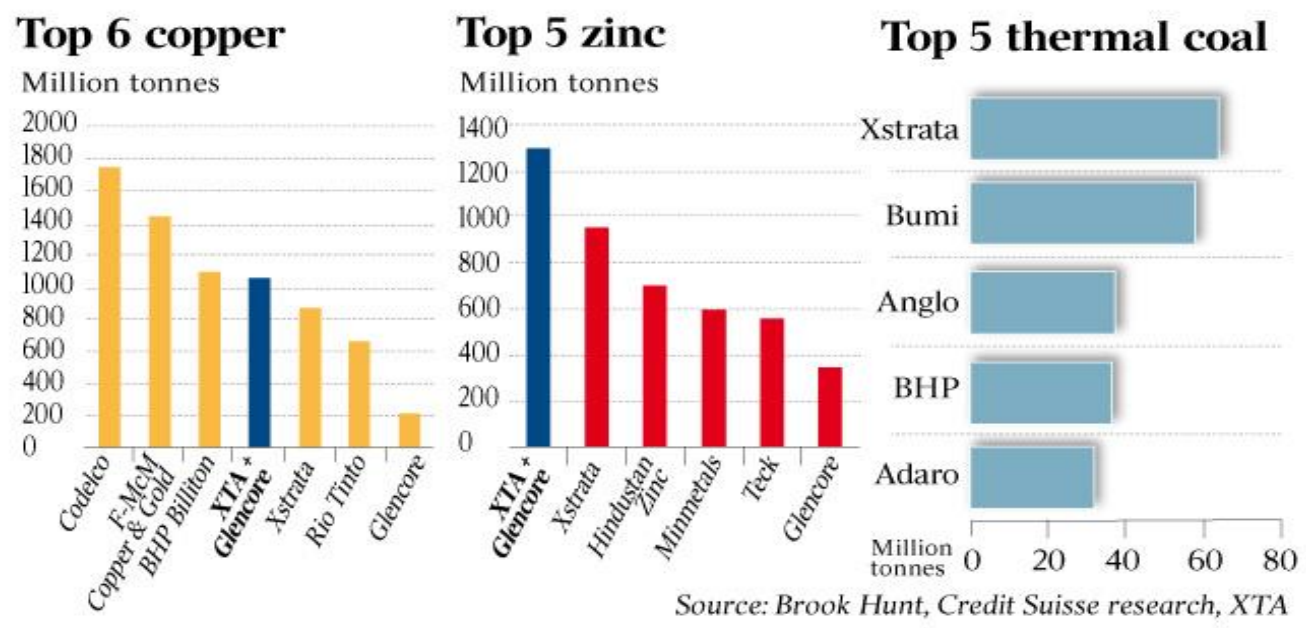

While the combined GlencoreXstrata business actions resemble best the actions outlined by Dunning (1977) in his Eclectic Paradigm, the company's market performance has been lower than its benchmark index.

The purpose of this research is the investigation of the Company's expansion strategy, as well as the identification of the reasons underlying its current financial performance. The remainder of this study is organized as follows: Section two presents the deployment of Glencore and Xstrata's growth strategy. In section three, relevant paradigms from literature are reviewed, while endeavoring to classify accordingly the company's strategic expansion. The societal and economic risks associated with company's operations are outlined in section four. The Company's reception by financial markets is presented in section five, and in section six we offer our conclusions.

\section{Glencore And Xstrata Strategy Deployment}

Glencore and Xstrata should always be seen as one entity or two companies with common goals working in different sections of the world commodities markets. Xstrata was created as a spinoff of the extracting business of Glencore in 2002. Glencore kept the trading portion of the business, while creating Xstrata to explore the global opportunities in mining. Scarcity is the main characteristic of natural resources. Throughout history, we see that wars have been fought over the acquisition of natural resources, providing tremendous power to the controlling entity. In today's economy, the world's industrial complex is more dependent than ever on these critical commodities. A fact that is not lost to Glencore Xstrata. Their overall business strategy is pointed, direct and simple. They seek to attain combined control of production and trade in oligopolistic global commodities markets. Controlling positions in oligopolistic resources markets are expected to produce excess profits in direct relation with the degree of monopolistic power held in each specific market. 
Overall business strategy as outlined above is deployed in every individual commodities market in an opportunistic format, using the global financial markets for the acquisition of production capacity. As CEO Ivan Glasenberg recently stated in an interview with Wall Street Journal “... my vision for this company in the next 10 years, ... I just want to do the right thing and get massive return on the equity, and I don't know where it's going to take me." (Miller, 2013). "Massive return on equity" has been the intermediate tactical tool because it facilitates access to financial markets for the financing of expansion strategy.

Figure 2. Xstrata's Value of Acquisitions and Net Debt

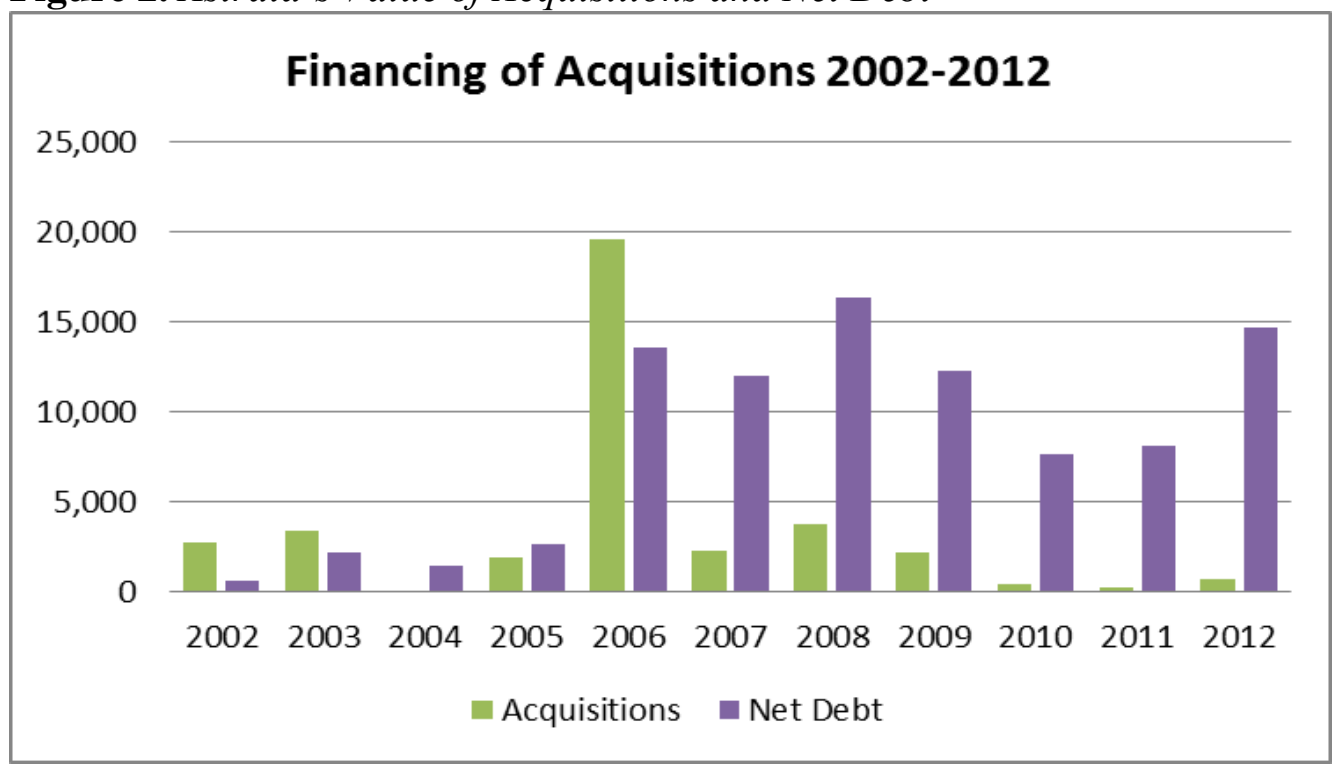

Essentially, GlencoreXstrata has been targeting geographic locations in which commodities can be extracted, manufactured, bought or sold, taking into account the numerous relevant pricing factors, including freight and product quality. By operating in a highly opportunistic model, the Company pursues growth and profit by sourcing, transporting, blending, storing or otherwise processing the relevant commodities wherever they find them. That model worked for many years and was rewarded by the financial markets. Table 1 shows the financing and acquisition mix deployed by Xstrata during the decade of 2002-2012 in Million dollars

The role of global financial markets is crucial at this point. Investigating the reception of the Company's goals and actions by the financial markets may reveal the perception of the markets about the suitability and future profitability of corporate actions. Glencore was a privately held company until 2008, so there are no reliable public financial data for the company's performance. Xstrata was listed in the primary market of the London Stock Exchange through an IPO offering in May 2002, as a spinoff of Glencore's extracting and mining business. As shown on Table 2, the first public revelation of Xstrata's major shareholdings reveals Glencore and global investment banking houses to control over $90 \%$ of the equity capital. While 
Glencore's holding is a natural outcome of the spinoff, holdings by investment banks are the product of private placement in the process of the IPO. Whether these placements were real investments to the full extent of the shareholdings or they just played the role of intermediate shares parking facility will never be publicly revealed. What can easily be observed ex-post is the magnitude of profit-taking by the "investment bankers" in 2005, three years after the IPO and three years before the global financial crisis.

Table 1. Xstrata Major Shareholders 2003 - 2006

\begin{tabular}{|c|c|c|c|}
\hline Shareholders & Feb-04 & Feb-05 & Feb-06 \\
\hline \multirow{2}{*}{$\begin{array}{c}\text { Glencore } \\
\text { Credit Suisse } \\
\text { Capital Group } \\
\text { Standard Life } \\
\text { Fidelity } \\
\text { Batis (N/P) }\end{array}$} & $40.17 \%$ & $40.39 \%$ & $15.97 \%$ \\
\cline { 2 - 4 } & $40.38 \%$ & $40.65 \%$ & $24.13 \%$ \\
\cline { 2 - 4 } & $10.87 \%$ & $3.99 \%$ & \\
\cline { 2 - 4 } & $4.01 \%$ & $3.14 \%$ & \\
\cline { 2 - 4 } & $3.02 \%$ & $4.27 \%$ & \\
\hline
\end{tabular}

Given the fact that market capitalization for the company was $\$ 14.82$ Billion at 2005 year end with a basic capital gain factor of at least $250 \%$ over the initial 2002 acquisition cost, profit taking from disposal of positions in 2006 amounted to approximately $\$ 1.4 \mathrm{~B}$ for the combined holdings of Capital Group, Standard Life and Fidelity Investments. The decline in ownership percentage in 2006 is caused by dilution due to non-participating in the seasoned equity offering.

While global markets were "dancing on the profits", allegation of violations on every aspect of ethical business behavior were mounting. Glencore and Xstrata, while creating jobs in third-world countries, had also created pollution, unsafe working conditions and had been accused of flagrantly violating employee human rights. They have been accused of exploiting their workers and hiring children to work in unsafe conditions in the minds (Peyer and Mercier, 2012). The effects of this exploitation have deservedly given Glencore and Xstrata a negative image. Their business practices have increasingly been viewed as questionable in many of the third world countries where they operate. They also appear to be indifferent to issues of sustainability and human rights, yet global financial markets still continue to overlook many of these behaviors in light of rent and profit seeking functions. Glencore and Xstrata's indifference to their social responsibility, call for further investigation on the part of responsible agents and governments.

\section{Review of the Literature}

The evolution of Glencore's and Xstrata's expansion strategy along with their final merger at the end, serves as a prime example of expansion strategy 
under the theories of Multi National Enterprises (MNE) and Foreign Direct Investment (FDI). We see the ex-post influence of Stephen Hymer's theory of internationalization. In Hymer's work (1960) we explore the unique features of FDI as a means by which the MNE maintains control over production activities outside its national boundaries. FDI becomes the primary means of creating international production. Hymer articulated the process of FDI as a means of international expansion by the MNE. He sees the MNE as using its international advantage to separate markets and remove competitors. Control over the use of global assets is required by the MNE in order to mitigate risk and attain unchallenged power. Hymer posits that control of a foreign subsidiary "is desired in order to remove competition between foreign enterprise and enterprise in other countries...or to appropriate fully the returns on certain skills and abilities" (p. 25). He further argues that the MNE "is a practical institutional device which substitutes for the market. The firm internalizes or supersedes the market" (p. 48). Hymer sees MNE as organizations openly displaying their power through the use of their collusive monopoly capital. He attributes a significant advantage to MNEs due to their ability to use internal markets across nations, move assets, relocate production at will, and use transfer pricing, all to their advantage. The MNE potential uncertainty comes in the form of the foreign governments. These governments can impact the political, cultural and societal dynamics which can impact their economic effectiveness. Or as in the case of GlencoreXstrata, they can welcome their presence and support their FDI, even if it is to the detriment of the citizens and the environment.

In 1977, John Dunning introduced the theory of the Eclectic Paradigm. Expanding on Hymer's prior work, his theory has served to elucidate why firms elect to employ FDI in order to engage in foreign markets rather than using other means such as joint ventures, strategic alliances or licensing agreements. The Paradigm is centered on the notion that FDI is the most effective vehicle for serving foreign markets when the firm possesses an ordered series of advantages that arise under conditions of imperfect competition. Dunning posits that in order to undertake FDI effectively, the company must first have a competitive advantage in its home country. The ownership or "O" advantages need to be transferrable to foreign markets. In addition, the business climate in the foreign market must be compliant and welcoming in order to allow the firm to take full advantage of its ownership position in the host country. The second set of advantages is referred to as the "L" advantages. This refers to location. The Internationalization refers to the "I" advantage. Here the firm benefits from reduction of transactions costs (Dunning, 2000).

As we examine the relationship between Glencore and Xstrata operational behavior and the Eclectic Paradigm there are many interesting parallels. With regard to "O", ownership, the firm must be able to transfer those advantages to foreign countries. This typically takes place in the form of intangible assets such as technology, patents, copyrights, branding and unique knowledge and skills. In addition, the financial strength of a company can serve to benefit a 
firm. The "O" advantage is enhanced where there is a "friendly" political environment that allows for untethered ownership. This provides the company with greater incentive to exploit those advantages in the host countries.

Location advantages are the result of economic differences among countries. In certain countries there may be inexpensive labor with special skills that will allow for higher levels of productivity. Access to natural resources and raw materials, is clearly a critical factor for many firms, particularly Glencore Xstrata. Internationalization becomes attractive when the "O" and "L" benefits exist. These benefits must be in sufficient to mitigate the potential risk of making a significant investment in a foreign country. The cost of having the firm manage and control all of its activities in the foreign country directly would be less than the cost of operating with a different structure. In the case of Glencore Xstrata, they have direct control of the value chain and thus it is in their best interest to utilize the "I" advantage.

We see that Stephen Hymer's theory of FDI, in combination with John Dunning's eclectic paradigm of international production (OLI) are applied to the operational behavior of GlencoreXstrata. Host countries have allowed the gradual building of dominant global market positioning in renewable (water, land, etc.) and depletable resources (minerals, metals, etc.), enhanced the firm's ability to seek global oligopolistic rents in otherwise competitive international commodity markets.

\section{Societal and Economic Risks}

\section{Oligopoly}

Oligopolies reduce competition which results in higher prices for the consumer and a lower quantity in the market. Often they lack efficiency and innovation as there is no serious competition to energize change. The oligopoly, thus, can effect investment in human capital, create higher unemployment, less investment in education, an undercapitalized labor force, and obsolescence. Oligopolies increase the concentration of wealth, which can be used to exert influence on governments. In GlencoreXstrata there are a select group of executives who are earn millions of dollars in compensation, while tens of thousands of employees in third-world-countries work for $\$ 1.25 \mathrm{a}$ day. In addition, since the mining industry is in the hands of so few, it places a heavy load on the environment, particularly in third world countries that are eager for employment and prone to corruption. Unless carefully monitored, indiscriminate mining can change the groundwater regime, throw off mud polluted with heavy metals, contaminating land and water, produce unsecured slag heaps through the use of toxic chemicals and unsafe practices. The severe environmental impacts are often the result of poorly executed and expedient extraction processes. 


\section{A Tarnished Reputation}

GlencoreXstrata is alleged to use unethical business tactics in order to secure its position in third-world-countries, accused of increasing corruption, tax evasion and money laundering. Michael Ross, author of The Oil Curse wrote "Unlike the case with many industries, minerals and energy are often owned by the state in the Third world." "And in a number of countries where Glencore operates, doing business means putting money into the pockets of repressive governments and corrupt rulers. In some of those places......it's hard to draw a line between what's legally corrupt and what's not."

\section{Global Regulation}

Global regulation in resource management is basically non-existent. For the most part, companies are self-regulating. They are responsible for applying reasonable social and environmental standards. A large global company like GlencoreXstrata can cause significant ecological destruction. There have been calls for more oversight, regulation and monitoring. Five non-government organizations have filed complaints with the Organisation for Economic Cooperation and Development (OECD) against GlencoreXstata, alleging illegal behavior ranging from tax-evasion, corruption and environmental destruction. While it is difficult to monitor such a large and diverse company, there are strong voices throughout the European Union demanding greater oversight. Policymakers are being pressured to pay closer attention to the natural resource oligopoly before it is too late.

\section{Glencorexstrata in the Global Financial Markets}

Market timing has always been a decisive factor in corporate capital budgeting and capital structure decisions. Empirical evidence ${ }^{1}$ suggests that IPOs are clustered within bull market periods, while debt issues are preferred during bear market periods. Since the turnaround time for the preparation of public listing ranges anywhere from one to two years ${ }^{2}$, we can reasonably assume that Glencore's management was entertaining the idea of listing towards the end of the bull market of the 90's. The advantage of attracting lowcost equity capital was weighted against the disadvantage of increased scrutiny and monitoring by the financial markets. Public listing would in turn increase the ability of the company to borrow funds and implement its expansion strategy. A logical ex-post conclusion lies on the fact that public listing of Xstrata (Glencore's mining operations) was the outcome of the value maximization process for Glencore's implementation of long-term expansion strategy. Even though timing of the actual IPO fell in the bear market segment of 2000-2004, possible financing constraints resulted in no postponement of the action. As can be seen in Figure 3, Xstrata's stock under-performed FTSE

\footnotetext{
${ }^{1}$ See Benninga et. al. (2005)

${ }^{2}$ depending on the satisfaction of legal and financial listing requirements by the existing corporate governance structure
} 
100 during the first year of public listing. From mid-2003 up until mid-2007, Xstrata's stock produced overwhelming excess returns over and above the market as proxied by FTSE 100. One $£$ invested in Xstrata's stock in 2002, would become $£ 3$ in 2007, providing an average annual return over $25 \%$.

Figure 3. Xstrata Stock Performance vs FTSE 100 (2002-2007)

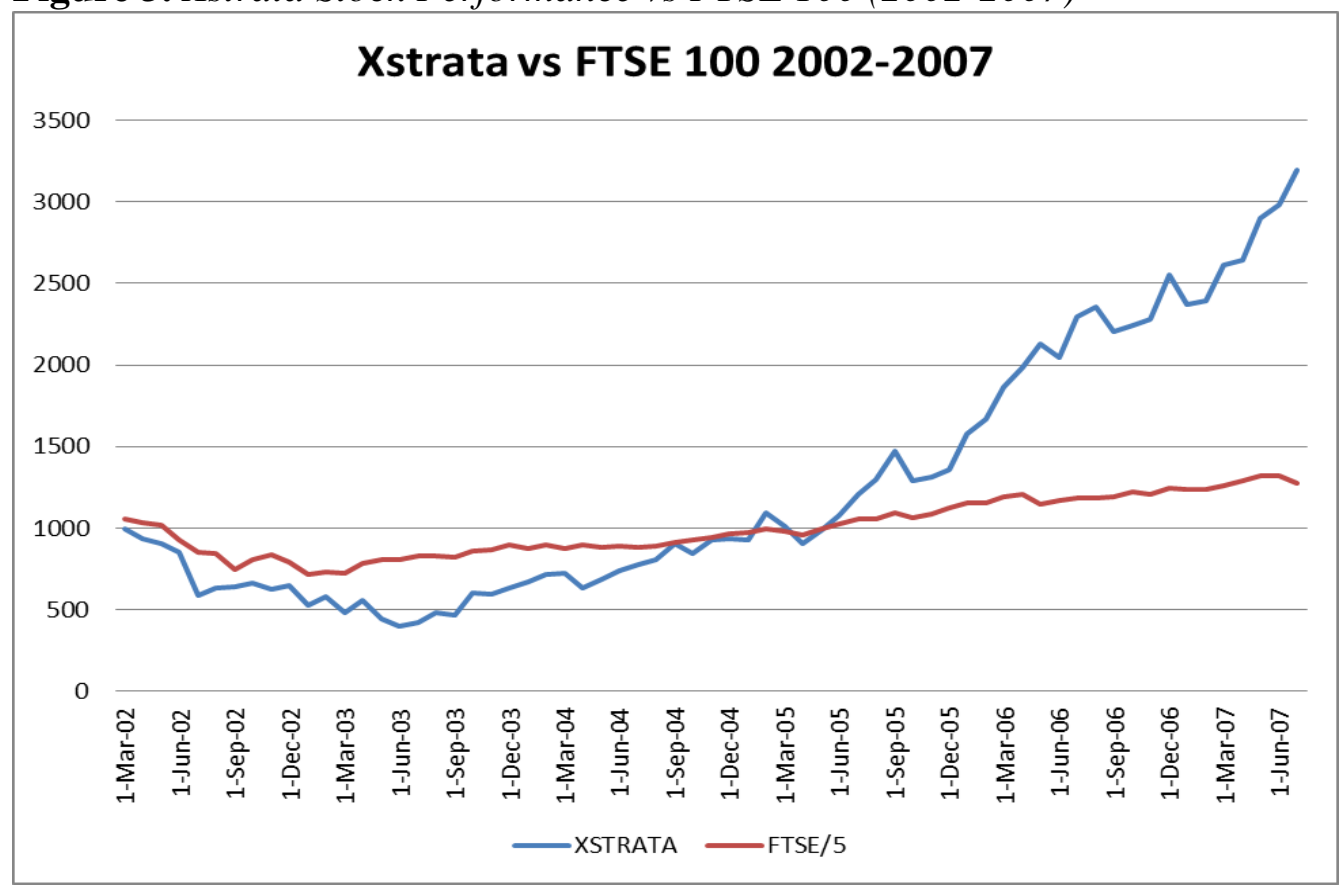

The global financial crisis of 2008 had a devastating impact on the stock performance of Xstrata, as illustrated in Figure 4 below. While attaining an overall high in early spring of 2008, Xstrata's stock price plummeted, losing $80 \%$ of its highest value within six months. Stock price fell and stayed below the IPO offering price for approximately one year (2008-2009). Considerable questions are raised regarding the performance of a company as big as Xstrata, while being a constituent of the FTSE 100 index. More surprisingly, Xstrata's stock price never recovered to the pre 2008 level. Stock-returns followed closely the index returns for the three consecutive years 2009-2011. During the years of under-performance, Glencore retained constant ownership stake in Xstrata, with a few new major shareholders from the institutional investor side appeared.

\footnotetext{
${ }^{1}$ For comparison purposes, FTSE 100 has been scaled by 5
} 
Figure 4. Xstrata Stock Performance vs FTSE 100 (2007-2011)

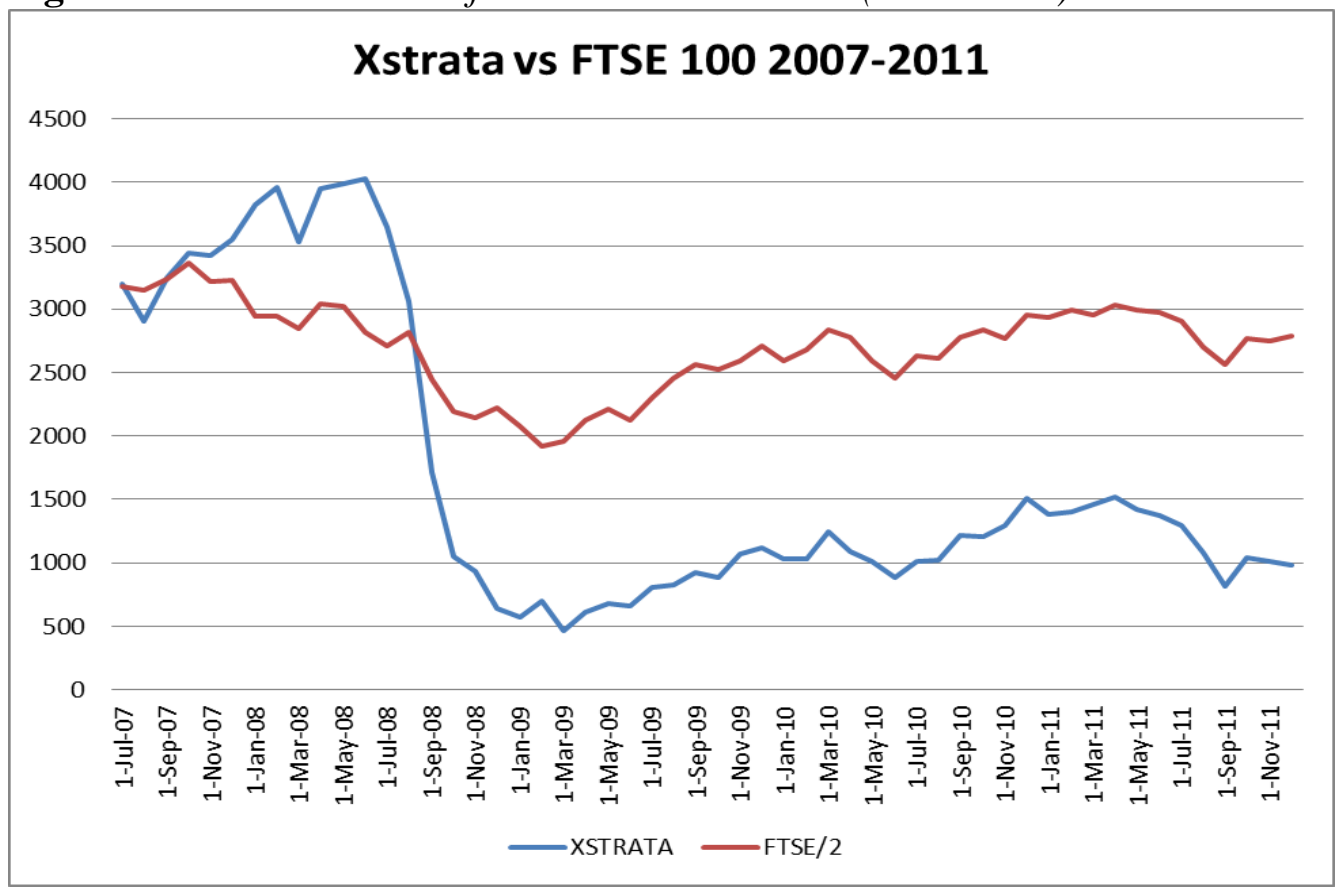

For a period of over three years, Xstrata failed to provide its shareholders (including Glencore) the "massive returns" promised. Markets did not value Xstrata's business in the same way anymore. What had changed still remains to be investigated? Was it the incorporation of corporate governance rules in most of the local stock exchanges all over the world? Was it the globalization effect of regulation and monitoring? Was it the inherent agency problem in handling so much cash by such a small and skilled management team? Was it the continuation of the financial crisis through the sovereign debt crisis in the European South? Definitely the reason was a combination of all the above.

Table 2. Xstrata Major Shareholders 2007 - 2009

\begin{tabular}{|c|c|c|c|}
\hline Shareholders & Dec-07 & Dec-08 & Dec-09 \\
\hline $\begin{array}{c}\text { Glencore } \\
\text { Capital Group } \\
\text { AXA } \\
\begin{array}{c}\text { Black Rock } \\
\text { Qatar Holding }\end{array}\end{array}$ & $34.40 \%$ & $34.45 \%$ & $34.38 \%$ \\
\cline { 2 - 4 } & & $5.27 \%$ & $4.94 \%$ \\
\cline { 2 - 4 } & $3.06 \%$ & $3.06 \%$ & \\
\cline { 2 - 4 } & & $4.21 \%$ & $3.02 \%$ \\
\hline
\end{tabular}

Under obvious pressure from global markets, in an effort to enhance shareholder's value, Glencore's management undertook the project of listing the company in London Stock Exchange (primary) with a secondary listing in Hong Kong in 2010. The scope of the undertaking might be twofold, providing

${ }^{1}$ For comparison purposes, FTSE 100 has been scaled by 2 
additional leverage to Glencore's management. On one hand market timing was perfect, being at the beginning of a new bull market as shown from the US market. On the other hand, with additional funds and support from the global markets, the Company could undertake more aggressive expansion steps, integrating vertically and increasing its monopolistic power in specific global markets, or expanding horizontally and diversify.

Consistent with Hymer's theory of FDI, a strategy of vertical integration would enhance shareholders' value, if the history of value creation lies with management implementing the strategy, under the condition of the existence of profitable investment opportunities in the sector. Even if there are no new profitable investment opportunities in the sector, diversification will provide at least the market returns, under the condition of the existence of such a management team that would align its interests with those of shareholders.

In fact, what followed Glencore's IPO in 2011 was the friendly takeover of Xstrata, signaling strongly that the aim was vertical integration combining under one management mining, manufacturing and trading of scarce resources in a global scale. The targeted merger would grant the new entity rent extracting abilities in major global commodities markets. That strategy would sound like sonata into the ears of international profit seeking arbitrageurs.

Figure 5. GlencoreXstrata Market Capitalization Trend

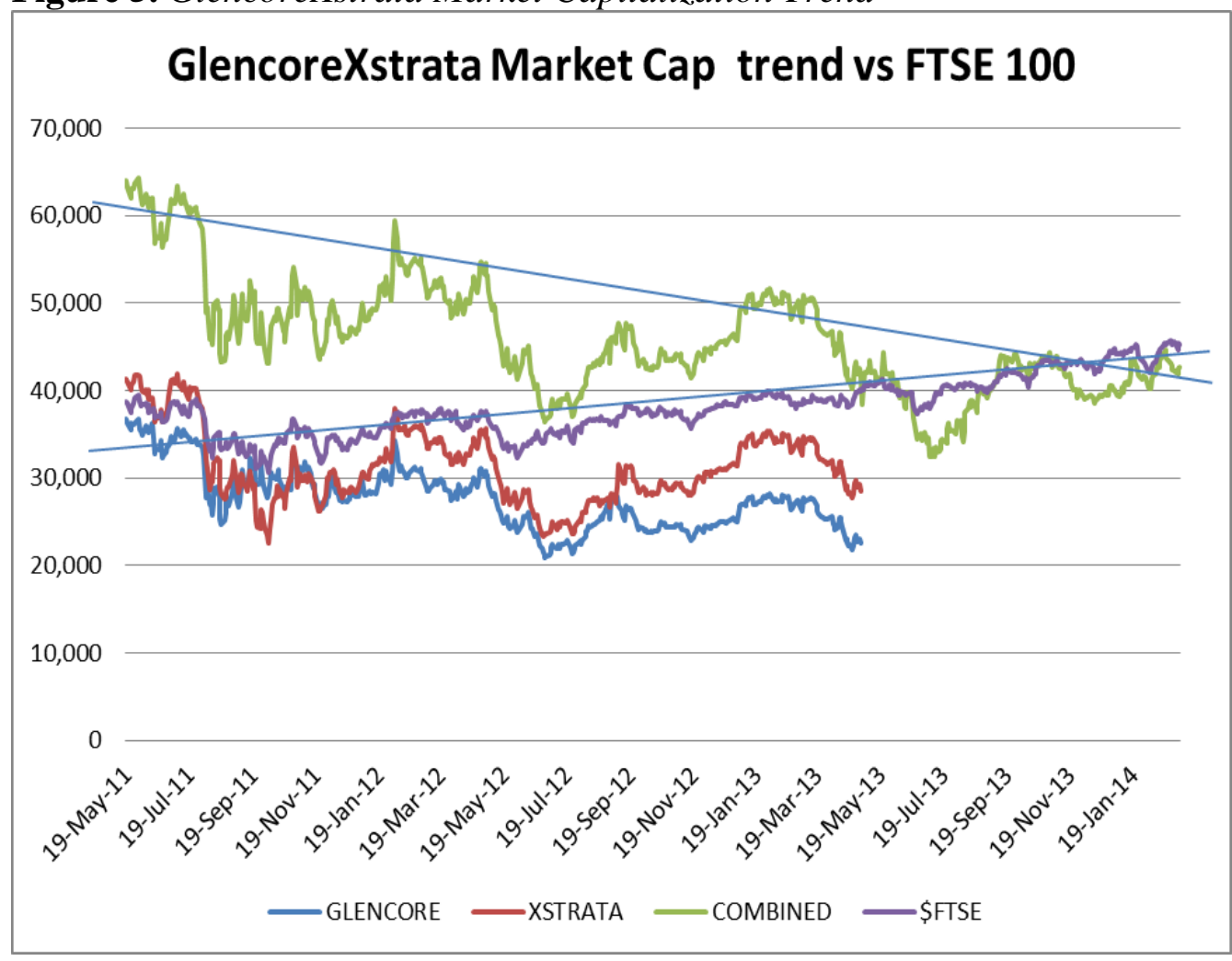

Despite management's expectations, ex-post observation reveals financial market's dissatisfaction towards the profitable implementation of Glencore's corporate strategy within the new institutional environment. In particular, as 
seen in Figure 5 above, during a clear bull market regime (2011-2013), the combined GlencoreXstrata market capitalization decreased even in nominal terms. It is clearly seen that the Company's market capitalization trend moved in the opposite direction when compared with the general market trend as proxied by FTSE 100. For illustration purposes all values in Figure 5 are in US dollar terms. Besides dollarization, FTSE has been scaled for comparison purposes.

Apparently, markets did not welcome GlencoreXstrata's overall behavior, at least during the last three years, or since the announcement of the intended merger. When the two companies were operating separately, they both had additional degrees of freedom and less scrutiny and monitoring from the markets. That would have been profitable for both management and financial stakeholders, since the companies could pursue their interests in legal and semi-legal ways through their global presence. Financial markets willingly and knowingly had been closing their eyes and ears in front of questionable business practices in return for "massive returns". What has been changed? What apparently has turned the tide against the unified company? What has increased effective monitoring?

A) Size has definitely changed. Now the company is greater than ever. Its actions my produce regulatory actions by either the US or EU. Then size at this level has an effect towards increased selfmonitoring.

B) Shareholder base has changed. According to table 3 below, the company's major shareholders list includes three of its oldest owners, but only for a total ownership stake of $14.56 \%$. Qatar Investments and Black Rock own 14.15\%. Most of the remaining outstanding stock is controlled by institutional investors. Institutional investors play a strong monitoring role adhering to corporate governance rules. Corporate governance and transparency deprive the company from its ability to realize "excess" profits from "sub-ethical" business practices.

Table 3. GlencoreXstrata Major Shareholders 2012 - 2013

\begin{tabular}{|c|c|c|}
\hline \multirow{2}{*}{ Major Shareholders } & Dec-12 & Dec-13 \\
\hline Ivan Glasenberg & $15.52 \%$ & $8.3 \%$ \\
\cline { 2 - 3 } Daniel Mate & $5.88 \%$ & $3.14 \%$ \\
\cline { 2 - 3 } Aris Moustakides & $5.84 \%$ & $3.12 \%$ \\
\cline { 2 - 3 } Tom Peterson & $5.16 \%$ & \\
\cline { 2 - 3 } Alex Beard & $4.51 \%$ & \\
\cline { 2 - 3 } Qatar Investments & & $8.42 \%$ \\
\cline { 2 - 3 } Black Rock & & $5.73 \%$ \\
\cline { 2 - 3 } & & \\
\cline { 2 - 3 }
\end{tabular}


While investigation of the reasons underlying financial markets behavior is a subject to be researched further, it seems that we are facing a clear size and monitoring effect, mainly due to the inherent agency problem of separation between ownership and control.

\section{Conclusions}

Glencore's search for profit and market share has driven it to merge with Xstrata. The combined company continues to pursue internationalization and global expansion. Mergers and acquisitions have been a significant strategy for both Glencore and Xstrata. The merger demonstrates Hymer's theory of internationalization as we look at this behemoth Multi National Enterprise who dominates the worldwide commodities markets. So while they are praised by the global financial community, their business practices continue to come under scrutiny. While the combined GlencoreXstrata business actions resemble best the actions outlined by Dunning (2000) in his Eclectic Paradigm, the company's market performance has been lower than its benchmark index. Further investigation is needed for the identification of the reasons underlying financial markets underpricing. Probable causes underlying recent underperformance are increased size and institutional monitoring. While increased size renders towards international regulation of resources, institutional monitoring supports the existence of agency problems.

Glencore's merger with Xstrata marks one of the world's largest tie-ups in recent history. The merger creates one of the world's largest commodity firms which can compete against rivals like BHP Billiton, Rio Tinto, and Anglo American PLC. It has created the world's largest thermal coal exporter, the largest zinc producer, and the third largest copper miner. Glencore has built a history of working with and investing in countries that are in turmoil or that have embargos. Its expansion and growth sometimes seem unethical but went unquestioned for a long period. This could create an illusion that all Glencore's business transactions and expansion procedures are normal; a new way to conduct international business; a new world other. But this is not the case. The new capital structure of GlencoreXstrata with controlling presence by institutional investors has increased monitoring creating adherence to corporate governance and increased transparency. Old Glencore's and Xstrata's real success came from operating in markets that scare off more risk-averse companies that fear running afoul of corporate governance laws in the United States and the European Union. Markets like the Democratic Republic of Congo which has copper, Columbia which has coal, Equatorial Guinea which has oil and natural gas, Kazakhstan where there is gold. All these countries have a heady, dangerous mix of extraordinary natural wealth and various degrees of instability, violence, and strongman leaders. The new GlencoreXstrata is not the same company anymore. That is one of the main reasons explaining why the Company has underperformed the market since the announcement of the merger. 
Glencore became a public company in 2011 and its size shocked many commodity traders. In fact, Glencore came to be known as "The biggest company you've never heard of." Upon going public, it became clear that Glencore controlled about $50 \%$ of the international tradable market in zinc, $60 \%$ in copper, $33 \%$ seaborne coal, $9 \%$ grain, and $3 \%$ of the daily global consumption of oil. Despite going public, the business model created and perfected by Marc Rich would be difficult for the New Glencore to undo. In today's superheated market for natural resources driven by booming emerging markets, Glencore wants to control the entire business chain, from mines and smelters to storage facilities for finished products, and from pumping oil to shipping it to refineries, while trading and hedging along the way. Glencore also makes money by leveraging information to take advantage of the wild swings that happen in the global commodities market.

When multinational corporations like GlencoreXstrata ensure full commitment to social consciousness acting with utmost concern with regard to their commitment by upholding rules and regulations of their home or host country, they become "quasi-utilities" for the global industry. As such they are monitored by complex interests represented by various types of institutional investors through their respective ownership and debt interests. Their effort is supported by the World Trade Organization (WTO), an institution created to promote free trade, involved in regulations governing FDI.

\section{References}

Benninga, S., Helmantel, M. and Sarig, O. 2004. The timing of initial public offerings. Journal of Financial Economics. 75 (2005), 115-132.

Brinded, L. 2013. Timeline and Factbox: Glencore and Xstrata Merger. International Business Times. (2013, 05 03). Retrieved from: http://www.ibtimes.co.uk/glen core-xstrata-merger-shares-trading-qatar-sovereign-464122

Dunning, J.H. 1977, Trade, Location of Economic Activity, and the Multinational Enterprise: A Search for an Eclectic Approach. In The International Allocation of Economic Activity, ed. B. Ohlin, P.O. Hesselborn and P.M. Wijkman. New York: Holmes and Meier.

Dunning, J.H. 2000. The Eclectic Paradigm as an Envelope for Economic and Business Theories of MNE Activity. International Business Review. 9. 2 (Apr. 2000), 163-190.

Dunning, J.H. and Pitelis, C. 2009. The Political Economy of Globalization Revisiting Stephen Hymer 50 Years On. MRPA Paper No. 23184.

Farchy, J. 2012. The Glencore shareholder reshuffle. Financial Times (2012, 10 26). Retrieved from: http://www.ft.com/intl/cms/s/0/3415ea88-1f36-11e2-b2ad-001 44feabdc0.html\#axzz33URMQhnM

Hymer, S. H. 1960. The International Operations of National Firms: A Study of Direct Foreign Investment. Cambridge: MIT Press.

Miller, J. 2013. Glasenberg: We Don't Do Work-Life Balance. The Wall Street Journal. (2013, 05 03). Retreaved from: http://blogs.wsj.com/moneybeat/2013/05 /03/glasenberg-we-dont-do-work-life-balance/ 
Peyer, C. and Mercier, F. 2012. Glencore in the Democratic Republic of Congo:profit before human rights and the environment. Bread for All. Retrieved from: http:// www.fastenopfer.ch/data/media/dokumente/news/2012/Glencore report.pdf

Pidd, H. Glaister, D., Smith, D \& Cobain, I. 2011. The Rise of Glencore: The biggest company You'Ve never heard of. The Guardian (2011, 05 19).

Ross, M. 2012. The Oil Curse: How Petroleum Wealth Shapes the Development of Nations. Princeton University Press. 
